\title{
Can Short Warning Messages Reduce Speeding Behaviour? Insights from A/B Testing
}

\author{
Pei Ying Chua (MPhil) \\ Andrea Liang (BA) \\ Yiling Kok (BA) \\ Grab, 138 Cecil Street Singapore \\ Ruimin He (PhD) \\ Grab, 138 Cecil Street Singapore
}

Lee Kuan Yew School of Public Policy, 469C Bukit Timah Road, Singapore

doi: 10.19044/esj.2017.v13n5p494 URL:http://dx.doi.org/10.19044/esj.2017.v13n5p494

\begin{abstract}
Speeding increases the likelihood and severity of an accident, and is the top cause of traffic fatalities. As such, it is important to study interventions such as warning signs and messages that may be able to reduce such behaviour. The main objective of this work was to study the effects of sending short warning messages on speeding behaviour. The study design was an A/B test - drivers who were detected to have sped were randomly assigned into treatment versus control groups. The treatment groups were sent a short warning message, while the control group did not receive any message. There were two types of messages sent - Harsh and Soft. Driver speeds were monitored in the subsequent weeks after the warning was sent out, and the number of repeat offenders and speeds in each group was tracked. We found that drivers who received a warning were 1.3 times less likely to speed in the subsequent week, with the Harsh warning message being 1.6 times more effective than the Soft message. We also found that the effects of harsh messages generally persisted longer than soft messages.
\end{abstract}

Keywords: Messaging, speeding, safety

\section{Introduction}

Speeding increases both the likelihood and severity of an accident (Finch, Kompfner, Lockwood, \& Maycock, 1994). It is the top cause of traffic fatalities - in 2012, 30\% of fatal road accidents in the United states involved speeding (NHSTA, 2012). This statistic is even more stark in South East Asia, where poor road conditions and frequent heavy monsoon rains prevail - the reported number of traffic fatalities in developing South East 
Asian countries averages 20 per 100,000 people (almost four times that of developed Asian countries such as Japan), and speeding accounts for 30-50\% of those incidents (Chisholm, Naci, Hyder, Tran, \& Peden, 2012; World Health Organization, 2013). In addition to the cost of pain and grief, there are also high economic costs related to aspects such as property damage, lost economic output, and administrative and legal fees. In countries such as the Philippines, this is estimated to be $\$ 70,000$ USD per fatal road accident, accumulating to over $\$ 1.3$ billion USD (De Leon, Cal, \& Sigua, 2005). As such, it is important to study interventions which can reduce the occurrence of excessive speeding.

According to the World Health Organization, 25-30\% of all crashes are estimated to be work-related (Bidasca \& Townsend, 2014). Grab is a leading provider of on-demand transportation services in South East Asia. With our drivers averaging 8-10 hours daily on the road, interacting with both customers and other road users, Grab deems it paramount to incorporate safety into all parts of our training and operations, including utilizing the data collected via the App to analyze and correct unsafe driving behavior.

Anti-speeding signs and vehicle-activated signs (which display the speed of a passing vehicle) remind drivers about legal speed limits, and have been found to reduce speeding behavior and speed-related fatalities (Chaurand, Bossart, \& Delhomme, 2015; Jomaa, 2013). Such signs have the potential to reach a large audience; however, the message is generic and may not resonate with the drivers, thereby diluting the effectiveness of the message. There are also limitations with using these signs, such as the costs of installation and maintenance, as well as finding appropriate locations to place them in order to achieve maximum impact. For example, signs on roads with higher traffic may reach more people, but these are not areas where people commonly speed. However, putting signs on quieter roads would mean that more signs are needed to reach the same number of people, thereby incurring higher costs.

Instead, sending personalized messages to individual drivers who have exhibited the speeding behavior is more targeted and therefore may provide a better return on investment. With the prevalence of global positioning system (GPS) and sensors on smartphones, information about driver locations and speed can be easily monitored to enforce safe driving. Reminders and warnings can also be easily sent via short phone messages. Studies have found that people alter their behavior, usually for the better, if they believe they are being watched. In particular, the Hawthorne studies found that workers become more productive if they believe they are being monitored (Roethlisberger, Dickson, Wright, Pforzheimer, \& Western Electric, 1939). In a similar vein, warning messages can improve driver safety. At the same time, the warning provides feedback to drivers who 
might not have been aware of their speeding behavior, therefore allowing them to self-moderate (Bandura, 2001).

Also, messaging delinquent drivers can serve as a reminder that reduces their propensity to speed as well as help them to monitor and selfregulate their actions to improve behavior (Bandura, 2001). The theory of planned behavior (Ajzen, 1985) asserts that the intention to perform a behavior (in this case, speeding) stems from attitudes towards speeding, social norms, and the perceived ease or difficulty of performing that behavior. Additionally, the behavior of speeding is a manifestation of both intention as well as perceived beliefs about the presence or absence of factors that can facilitate or impede the speeding behavior - meaning that people will speed less when they perceive that there are factors that prohibit speeding. By sending these messages to the drivers, there is a deterrent factor because drivers may see the message as a warning that Grab will take action against unsafe drivers and possibly remove them from the platform.

Targeted messages have also been found to be more effective in reaching and changing behavior (Schmid, Rivers, Latimer, \& Salovey, 2008). Research by Uskul and Millar has found differences in how people from Asian and Western countries respond to different tones, with harsher messages being more effective in Asian populations (Millar \& Millar, 2000; Uskul, Sherman, \& Fitzgibbon, 2009). Therefore, we decided to investigate not just the effect of a warning effect, but also the effects of different messaging tones. Further, the frequency of warnings must be optimized excessively frequent warnings may desensitize the driver and make him indifferent to subsequent warnings. Looking at how long the effect of a single warning is retained will provide valuable insights and guide subsequent work on finding the optimal frequency for sending out warnings.

As such, we decided to test the effectiveness of warning messages in reducing drivers' propensity to speed, with the hypothesis that drivers who receive warning messages would be less likely to speed than drivers who do not receive a warning, and that harsher warning tones would produce greater deterrent effects.

In this paper, we evaluate the effect of sending short warning messages to drivers who exhibit speeding behavior. In particular, we were interested to study the following:

(i) If warnings would reduce drivers' propensity to speed;

(ii) How long the effects of a warning would last; and

(iii) Whether different message tones would have different effectiveness.

Results from our study showed that (1) warning messages reduced the likelihood of continued speeding in subsequent weeks, (2) effects lasted for 2 
weeks, and (3) Harsh warnings were more effective than Soft warnings in achieving this outcome.

\section{Methods}

\subsection{Overview of Methodology}

The study was conducted in 5 countries across 4 weeks:

- Week 0 (Pre-Warning): In Week 0, drivers' GPS data was monitored in order to identify speeding drivers. The speed limit used was the legal maximum speed limit in individual countries that the drivers were from. Some of these drivers were then randomly assigned into treatment and control groups.

- Week 1 (Post-Warning): In order to assess if drivers would respond positively to warnings against speeding, drivers in the treatment groups received a short warning message on their phones at the beginning of Week 1. Those in the treatment group received one of two messages (Table 1):

(a) A harsh warning message on their phones, sternly informing them about the penalties of speeding; or

(b) A milder message, cautioning them against speeding.

These messages were translated into the national languages of the respective countries. Those in the control group did not receive any message.

- Weeks 2 and 3 (Retention W1 and Retention W2): These were the subsequent two weeks, termed the Retention Week 1 and Retention Week 2. No further messages were sent out during this period, although we continued to monitor speeding patterns in order to assess whether the effects of warning had been retained.

Table 1: Example of messages sent to drivers.

\begin{tabular}{|l|l|}
\hline Group & Message \\
\hline Harsh & $\begin{array}{l}\text { Hi [Insert Driver's Name], many accidents are caused by speeding. Last week, } \\
\text { we caught you speeding [Insert Number] times. We will impose strict sanctions } \\
\text { on drivers who commit unsafe acts and will not hesitate to terminate any unsafe } \\
\text { driver. }\end{array}$ \\
\hline Soft & $\begin{array}{l}\text { Hi [Insert Driver's Name], we care about your safety. Last week, we detected } \\
\text { you speeding [Insert Number] times. Remember that your family is counting on } \\
\text { you to get home safely. Please drive at a safe speed because the lives of your } \\
\text { passengers and everyone on the road depend on you. }\end{array}$ \\
\hline Control & No message sent. \\
\hline
\end{tabular}

\subsection{How did we identify the speeding drivers?}

Driver locations were identified through pings from their smartphone's GPS. These were then used to estimate each driver's speed, and cross-referenced to the maximum national speed limit to determine 
instances of speeding. Speeding drivers were defined as those who exceeded the speed limit at least two times within a single minute.

\subsection{Driver Groupings}

The data were analyzed anonymously. Drivers were randomly assigned into the Harsh, Soft and Control groups. Table 2 shows the exact number of drivers in each group.

Table 2: Breakdown of drivers in each group.

\begin{tabular}{|c|c|c|c|}
\hline Speed Limit & Harsh & Soft & Control \\
\hline $\mathbf{1 2 0} \mathbf{~ k m / h}$ & 186 & 193 & 158 \\
\hline $\mathbf{1 0 0} \mathbf{~ k m / h}$ & 582 & 581 & 709 \\
\hline $\mathbf{8 0} \mathbf{~ k m / h}$ & 205 & 188 & 214 \\
\hline TOTAL & $\mathbf{9 7 3}$ & $\mathbf{9 6 2}$ & $\mathbf{1 0 8 1}$ \\
\hline
\end{tabular}

\subsection{Statistical Analyses}

Drivers who are less active spend less time on the roads, therefore the occurrence of speeding incidents detected will also decrease. Prior to conducting detailed analyses, we checked to see if, between the groups, there was any difference in the percentage of drivers who maintained their original activity. A one-way ANOVA found that there was no statistical difference between the groups (Table 3).

Table 3: Percentage of drivers who maintained their original activity in the subsequent weeks.

\begin{tabular}{|c|c|c|c|c|}
\hline Group & $\begin{array}{c}\text { Week 0 } \\
\text { (Pre- } \\
\text { warning) }\end{array}$ & $\begin{array}{c}\text { Week 1 } \\
\text { (Post- } \\
\text { warning) }\end{array}$ & $\begin{array}{c}\text { Week 2 } \\
\text { (Retention } \\
\text { W1) }\end{array}$ & $\begin{array}{c}\text { Week 3 } \\
\text { (Retention } \\
\text { W2) }\end{array}$ \\
\hline Harsh Warning & $100.00 \%$ & $47.38 \%$ & $41.11 \%$ & $46.66 \%$ \\
\hline Soft Warning & $100.00 \%$ & $44.59 \%$ & $39.09 \%$ & $45.95 \%$ \\
\hline $\begin{array}{c}\text { No Warning } \\
\text { (Control) }\end{array}$ & $100.00 \%$ & $46.62 \%$ & $39.96 \%$ & $47.27 \%$ \\
\hline P-values & N/A & $p=0.178$ & $p=0.413$ & $p=0.385$ \\
\hline
\end{tabular}

ANOVAs were then run to understand the effects of and interactions between messaging, speed limits and time on speeding behavior. Specifically, we were interested in the effects of messaging and speed limit on speeding behavior, and how this behavior changes over time (1 week, 2 weeks, 3 weeks). Messaging and speed limits were between-subject factors, while time was a within-subject factor. There were three levels of messaging 
(Harsh, Soft, and None), three levels of speed limit $(80 \mathrm{~km} / \mathrm{h}, 100 \mathrm{~km} / \mathrm{h}$ and $120 \mathrm{~km} / \mathrm{h}$ ), and three levels of time (Week 1, Week 2 and Week 3). Two dependent variables were tested separately - a discrete variable describing whether the driver was found to be speeding (yes or no), and a continuous variable describing the drivers' speed (in $\mathrm{km} / \mathrm{h}$ ).

\section{Results and Discussion}

\subsection{Effect of warnings on number of speeding drivers}

3.1.1. The number of speeding drivers fell sharply immediately after the warnings were sent out.

Overall, we saw a sharp decrease in the number of speeding drivers between Week 0 and the subsequent weeks. Given that between the groups, there was no statistical difference in the percentage of drivers who maintained their original activity (see Table 3), we can normalize the numbers with respect to the control group. From Table 4 and Figure 1, we see that in Week 1 (immediately after the warning message was sent out), there were fewer repeat offenders in the treatment groups compared to the control group, and the Harsh message was more effective than the Soft message. In the subsequent weeks (Week 2 and Week 3), the number of speeding drivers started to rise again, indicating that the initial effects of the warning message were wearing off.

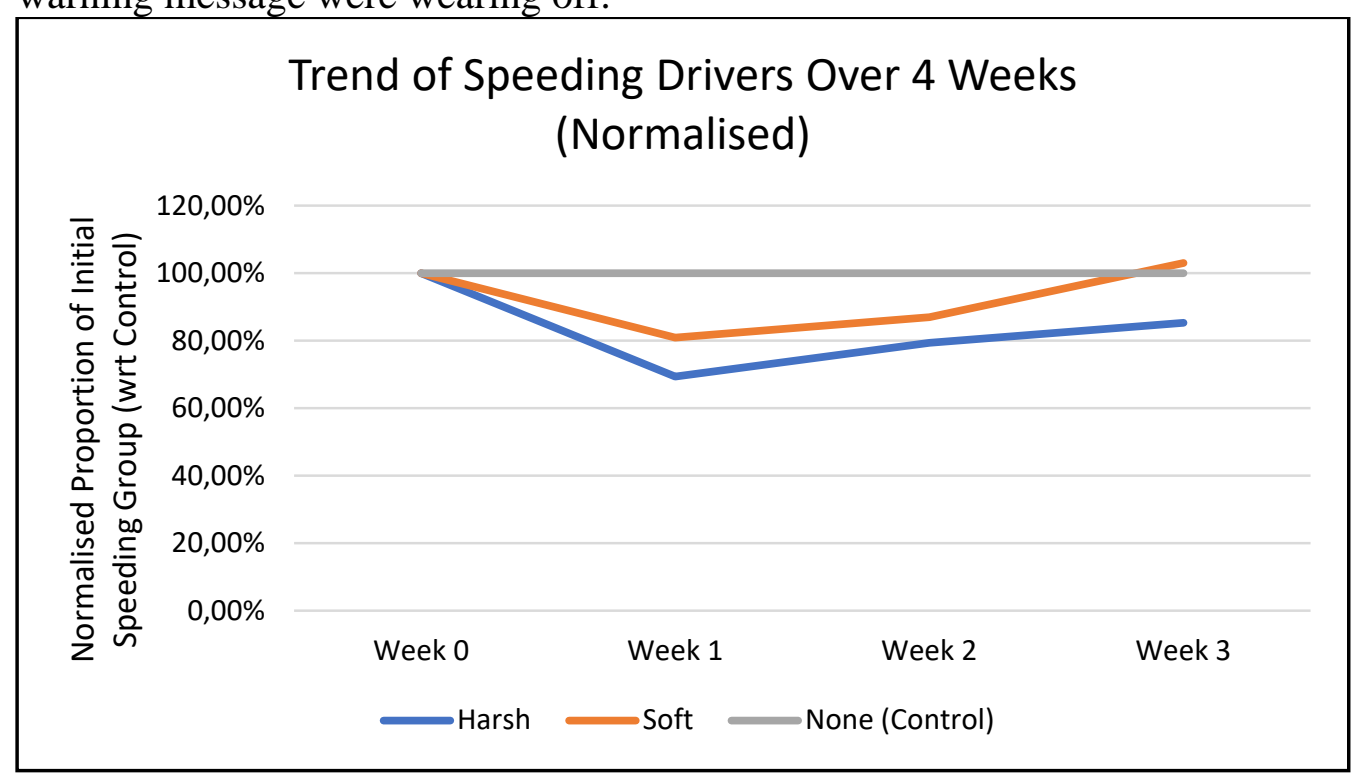

Figure 1: Trend of normalized percentage of repeat offenders over 4 weeks, relative to the Control Group. 
Table 4: Normalized percentage of repeat offenders over 4 weeks, with respect to the Control Group.

\begin{tabular}{|c|c|c|c|c|}
\hline Group & $\begin{array}{c}\text { Week 0 } \\
\text { (Pre- } \\
\text { warning) }\end{array}$ & $\begin{array}{c}\text { Week 1 } \\
\text { (Post- } \\
\text { warning) }\end{array}$ & $\begin{array}{c}\text { Week 2 } \\
\text { (Retention } \\
\text { W1) }\end{array}$ & $\begin{array}{c}\text { Week 3 } \\
\text { (Retention } \\
\text { W2) }\end{array}$ \\
\hline Harsh Warning & $100.00 \%$ & $69.34 \%$ & $79.36 \%$ & $85.27 \%$ \\
\hline Soft Warning & $100.00 \%$ & $80.89 \%$ & $86.92 \%$ & $103.01 \%$ \\
\hline $\begin{array}{c}\text { No Warning } \\
\text { (Control) }\end{array}$ & $100.00 \%$ & $100.00 \%$ & $100.00 \%$ & $100.00 \%$ \\
\hline
\end{tabular}

\subsubsection{Groups that received a warning were approximately $25 \%$ less} likely to speed in the following week.

We found that warnings reduced the occurrence of speeding significantly. On average, drivers in groups that received a warning message (either Harsh or Soft) were $24.91 \%$ less likely to speed in Week 1, 16.87\% less likely to speed in Week 2, and 5.93\% less likely to speed in Week 3 (Table 5). This is in line with our initial hypothesis that drivers who receive warning messages would be less likely to speed, in a similar vein with the Hawthorne studies (Roethlisberger et al., 1939).

Table 5: Percentage of repeat offenders in Treatment and Control groups. Significant differences are indicated at $* 1 \%, * * 5 \%$ and $* * * 1 \%$ levels.

\begin{tabular}{|c|c|c|c|c|}
\cline { 2 - 5 } \multicolumn{1}{c|}{} & \multicolumn{3}{c|}{ Percentage of Repeat Offenders } & \multicolumn{2}{c|}{ Percentage Differences } \\
\hline Week & $\begin{array}{c}\text { Treatment } \\
\text { (t) }\end{array}$ & $\begin{array}{c}\text { Control } \\
\text { (c) }\end{array}$ & $\begin{array}{c}\text { Dbsolute } \\
\text { Difference } \\
\text { (percentage } \\
\text { points) } \\
\text { (t-c) }\end{array}$ & $\begin{array}{c}\text { Relative } \\
\text { Difference } \\
\text { (t-c)/c }\end{array}$ \\
\hline $\begin{array}{c}\text { Week 1 } \\
\text { (Post-warning) }\end{array}$ & $19.59 \%$ & $26.09 \%$ & -6.50 p.p.*** & $-24.91 \%$ \\
\hline $\begin{array}{c}\text { Week 2 } \\
\text { (Retention W1) }\end{array}$ & $22.07 \%$ & $26.55 \%$ & -4.48 p.p.*** & $-16.87 \%$ \\
\hline $\begin{array}{c}\text { Week 3 } \\
\text { (Retention W2) }\end{array}$ & $27.78 \%$ & $29.53 \%$ & -1.75 p.p. & $-5.93 \%$ \\
\hline
\end{tabular}

A three-way mixed ANOVA was run to understand the effects of messaging, speed limits and time on speeding behavior. There were three levels of messaging (Harsh, Soft, and None), three levels of speed limit $(80 \mathrm{~km} / \mathrm{h}, 100 \mathrm{~km} / \mathrm{h}$ and $120 \mathrm{~km} / \mathrm{h}$ ), and three levels of time (Week 1, Week 2 and Week 3). The dependent variable was a discrete variable indicating whether the driver was found to be speeding (yes or no).

The three-way interaction between time, messaging and speed limits was not statistically significant, $F(2,6010)=1.302, p=0.237$. Looking into the two-way interactions, there was a statistically significant two-way 
interaction between time and messaging, $F(2,6010)=6.015, p=0.004$. All other two-way interactions were not statistically significant $(p>0.05)$.

We then looked more closely at main effects of messaging and time to determine the factor(s) contributing to significant effects. There was a statistically significant simple main effect of messaging at in the first two weeks - Week 1: $F(1,3005)=5.711, p=0.003$; Week 2: $F(1,3005)=$ 7.569, $p=0.001$. There was no significant main effect of messaging in Week 3. All other simple main effects were also not significant across all three weeks. Note that statistical significance of a simple main effect was accepted at a Bonferroni-adjusted alpha level of 0.025 .

\subsubsection{The Harsh warning message was up to $1.4 x$ more effective than the Soft message in reducing the number of speeding drivers.}

The Harsh warning was generally more effective than the Soft warning (Table 6). The largest difference between the Harsh and Soft effects was seen in Week 1 for countries with the $120 \mathrm{~km} / \mathrm{h}$ speed limit - the Harsh message was $1.37 \mathrm{x}$ more effective than the Soft message.

Table 6: (a) Percentage of repeat offenders in each group. (b) Difference between the percentage of repeat offenders in treatment versus control groups. Significant differences are indicated at $* 1 \%, * * 5 \%$ and $* * * 1 \%$ levels, based on pairwise comparisons with

Bonferroni corrections.

\begin{tabular}{|c|c|c|c|c|c|c|c|}
\hline & & \\
\hline & & \multicolumn{3}{|c|}{ (a) \% of Repeat Offenders } & \multicolumn{3}{|c|}{ (b) Between-Group Comparisons } \\
\hline Week & Speed & $\begin{array}{c}\text { Harsh } \\
\text { (h) }\end{array}$ & $\begin{array}{l}\text { Soft } \\
\text { (s) }\end{array}$ & $\begin{array}{l}\text { Control } \\
\text { (c) }\end{array}$ & $\begin{array}{c}\text { Harsh - } \\
\text { Control } \\
\text { (percentage } \\
\text { points) } \\
\text { (h-c) }\end{array}$ & $\begin{array}{c}\text { Soft - } \\
\text { Control } \\
\text { (percentage } \\
\text { points) } \\
\text { (s-c) }\end{array}$ & 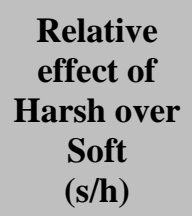 \\
\hline \multirow{4}{*}{$\begin{array}{c}\text { Week } 1 \\
\text { (Post- } \\
\text { warning) }\end{array}$} & $120 \mathrm{~km} / \mathrm{h}$ & $19.35 \%$ & $26.42 \%$ & $30.38 \%$ & $\begin{array}{l}-11.03 \\
\text { p.p. }\end{array}$ & -3.96 p.p. & 1.37 \\
\hline & $100 \mathrm{~km} / \mathrm{h}$ & $19.07 \%$ & $22.03 \%$ & $28.35 \%$ & -9.28 p.p. ${ }^{* * *}$ & -6.32 p.p. & 1.16 \\
\hline & $80 \mathrm{~km} / \mathrm{h}$ & $14.15 \%$ & $12.77 \%$ & $15.42 \%$ & -1.27 p.p. & -2.65 p.p. & 0.90 \\
\hline & Total & $18.09 \%$ & $21.10 \%$ & $26.09 \%$ & -8.00 p.p. ${ }^{* * *}$ & -4.99 p.p. & 1.17 \\
\hline \multirow{4}{*}{$\begin{array}{c}\text { Week } 2 \\
\text { (Retention } \\
\text { W1) }\end{array}$} & $120 \mathrm{~km} / \mathrm{h}$ & $23.12 \%$ & $25.39 \%$ & $27.22 \%$ & -4.10 p.p.*** & -1.83 p.p. & 1.10 \\
\hline & $100 \mathrm{~km} / \mathrm{h}$ & $21.48 \%$ & $24.44 \%$ & $28.49 \%$ & -7.01 p.p. ${ }^{* *}$ & -4.05 p.p. & 1.14 \\
\hline & $80 \mathrm{~km} / \mathrm{h}$ & $18.05 \%$ & $16.49 \%$ & $19.63 \%$ & -1.58 p.p. & -3.14 p.p. & 0.91 \\
\hline & Total & $21.07 \%$ & $23.08 \%$ & $26.55 \%$ & -5.48 p.p. ${ }^{* *}$ & -3.47 p.p. & 1.10 \\
\hline \multirow{4}{*}{$\begin{array}{c}\text { Week } 3 \\
\text { (Retention } \\
\text { W2) }\end{array}$} & $120 \mathrm{~km} / \mathrm{h}$ & $33.12 \%$ & $34.82 \%$ & $32.79 \%$ & 0.34 p.p. & 2.03 p.p. & 1.05 \\
\hline & $100 \mathrm{~km} / \mathrm{h}$ & $25.49 \%$ & $31.81 \%$ & $32.38 \%$ & -6.89 p.p. & -0.57 p.p. & 1.25 \\
\hline & $80 \mathrm{~km} / \mathrm{h}$ & $17.08 \%$ & $18.60 \%$ & $17.67 \%$ & -0.59 p.p. & 0.93 p.p. & 1.09 \\
\hline & Total & $25.19 \%$ & $30.42 \%$ & $29.53 \%$ & -4.34 p.p. & 0.90 p.p. & 1.21 \\
\hline
\end{tabular}

Work on messaging and framing has found that East-Asians respond better to loss-framed messages (Uskul et al., 2009). This is contrary to 
findings in typical Western countries, where people are more receptive to gain-framed messages (Millar \& Millar, 2000). In the current study, the Harsh message is more similar to a 'loss' message that focusing on the consequences of speeding, while the Soft message leans towards being a 'gain' message that focuses on the benefits of increased safety. In line with this, our results showed that the Harsh message was more effective than the Soft message. More detailed experiments that test a wider range of messages is required to understand the specific nuances here.

\subsubsection{Effects of the Harsh warning persisted after 2 weeks.}

The effects of the Harsh warning persisted for 2 weeks, while the effects of the Soft message persisted for 1 week. After the first Retention Week, there was about 67-68\% retention of Harsh and Soft message effects; after the second Retention Week, there was about 48\% retention of the Harsh message effects but the Soft message effects were completely eliminated (Table 7).

Table 7: Percentage of effect that persists for Harsh and Soft treatment groups, relative to the effect in Week 1.

\begin{tabular}{|c|c|c|}
\hline Week & Harsh Group & Soft Group \\
\hline $\begin{array}{c}\text { Week 1 to 2 } \\
\text { (Warning to Retention W1) }\end{array}$ & $67.32 \%$ & $68.32 \%$ \\
\hline $\begin{array}{c}\text { Week 1 to 3 } \\
\text { (Warning to Retention W2) }\end{array}$ & $47.95 \%$ & $0.00 \%$ \\
\hline
\end{tabular}

That the effects fall off after 2 weeks are in line with other prompting frequency studies that remind participants to perform activities such as exercise regularly - these found that weekly reminders were more effective compared to reminders sent out every 3 weeks (Lombard, Lombard, \& Winett, 1995).

\subsection{Effect of warning on driver speeds}

\subsubsection{Drivers who had received the Harsh warning message but continued to speed did so at lower speeds compared to the control group (up to $8 \mathrm{~km} / \mathrm{h}$ slower).}

The occurrence of fatalities during a crash is also related to the speed of the vehicle(s) involved - a 5\% reduction in average vehicle speed is estimated to reduce the number of fatal crashes by as much as 30\% (Global Road Safety Partnership, 2015). We observed that while some drivers continued to drive above the respective legal limits, drivers who had received the warning generally did so at a lower speed compared to the control group (Tables 8 and 9). 
A one-way ANOVA with pairwise comparisons was conducted to determine if the differences between the treatment and control groups was significant. Between Week 1 and Week 0, there were significant treatment effects for both the Harsh and Soft treatment groups, and the effects tapered off in subsequent weeks (Table 10).

Table 8: Median of speeds above the speed limit $(\mathrm{km} / \mathrm{h})$ of each group in each week.

\begin{tabular}{|c|c|c|c||c|c|c||c|c|c|}
\cline { 2 - 9 } \multicolumn{1}{c|}{} & \multicolumn{3}{c||}{$\mathbf{1 2 0} \mathbf{~ k m} / \mathbf{h}$} & \multicolumn{3}{|c||}{$\mathbf{1 0 0} \mathbf{~ k m} / \mathbf{h}$} & \multicolumn{3}{|c|}{$\mathbf{~ k m / h}$} \\
\hline & $\begin{array}{c}\text { Harsh } \\
\text { Group }\end{array}$ & $\begin{array}{c}\text { Soft } \\
\text { Group }\end{array}$ & $\begin{array}{c}\text { Control } \\
\text { Group }\end{array}$ & $\begin{array}{c}\text { Harsh } \\
\text { Group }\end{array}$ & $\begin{array}{c}\text { Soft } \\
\text { Group }\end{array}$ & $\begin{array}{c}\text { Control } \\
\text { Group }\end{array}$ & $\begin{array}{c}\text { Harsh } \\
\text { Group }\end{array}$ & $\begin{array}{c}\text { Soft } \\
\text { Group }\end{array}$ & $\begin{array}{c}\text { Control } \\
\text { Group }\end{array}$ \\
\hline $\begin{array}{c}\text { Week 0 } \\
\text { (Pre- } \\
\text { warning) }\end{array}$ & 127.47 & 126.77 & 128.18 & 111.31 & 110.85 & 111.32 & 90.02 & 89.75 & 88.73 \\
\hline $\begin{array}{c}\text { Week 1 } \\
\text { (Post- } \\
\text { warning) }\end{array}$ & 121.41 & 122.52 & 128.73 & 105.24 & 106.77 & 110.21 & 87.32 & 86.90 & 87.35 \\
\hline $\begin{array}{c}\text { Week 2 } \\
\text { (Retention } \\
\text { W1) }\end{array}$ & 122.15 & 122.89 & 127.86 & 105.78 & 105.98 & 111.86 & 87.58 & 87.45 & 87.24 \\
\hline $\begin{array}{c}\text { Week 3 } \\
\text { (Retention } \\
\text { W2) }\end{array}$ & 124.87 & 123.06 & 126.52 & 106.53 & 106.03 & 111.07 & 87.20 & 86.83 & 86.88 \\
\hline
\end{tabular}

Table 9: Difference in median speeds $(\mathrm{km} / \mathrm{h})$ between subsequent weeks and Week 0.

\begin{tabular}{|c|c|c|c||c|c|c||c|c|c|}
\cline { 2 - 9 } \multicolumn{1}{c|}{$\begin{array}{c}\text { Difference } \\
\text { between } \\
\begin{array}{c}\text { Week N and } \\
\text { Week 0 }\end{array}\end{array}$} & $\begin{array}{c}\text { Hars } \\
\mathbf{h} \\
\text { Grou } \\
\mathbf{p}\end{array}$ & $\begin{array}{c}\text { Soft } \\
\text { Grou } \\
\mathbf{p}\end{array}$ & $\begin{array}{c}\text { Contr } \\
\mathbf{o l} \\
\text { Group }\end{array}$ & $\begin{array}{c}\text { Gars } \\
\mathbf{h} \\
\text { Grou } \\
\mathbf{p}\end{array}$ & $\begin{array}{c}\text { Soft } \\
\text { Grou } \\
\mathbf{p}\end{array}$ & $\begin{array}{c}\text { Contr } \\
\mathbf{o l} \\
\text { Group }\end{array}$ & $\begin{array}{c}\text { Hars } \\
\mathbf{h} \\
\text { Grou } \\
\mathbf{p}\end{array}$ & $\begin{array}{c}\text { Soft } \\
\text { Grou } \\
\mathbf{p}\end{array}$ & $\begin{array}{c}\text { Contr } \\
\mathbf{o l} \\
\text { Group }\end{array}$ \\
\hline $\begin{array}{c}\text { Week 1 - } \\
\text { Week 0 }\end{array}$ & -6.06 & -4.25 & 0.55 & -6.07 & -4.08 & -1.11 & -2.7 & -2.85 & -1.38 \\
\hline $\begin{array}{c}\text { Week 2 - } \\
\text { Week 0 }\end{array}$ & -5.32 & -3.88 & -0.32 & -5.53 & -4.87 & 0.54 & -2.44 & -2.3 & -1.49 \\
\hline $\begin{array}{c}\text { Week 3 - } \\
\text { Week 0 }\end{array}$ & -2.6 & -3.71 & -1.66 & -4.78 & -4.82 & -0.25 & -2.82 & -2.92 & -1.85 \\
\hline
\end{tabular}

Table 10: Comparing the difference in median speeds $(\mathrm{km} / \mathrm{h})$ for treatment versus control group. Significant differences are indicated at $* 1 \%$, * $5 \%$ and $* * * 1 \%$ levels, based on pairwise comparisons.

\begin{tabular}{|c|c|c||c|c||c|c|}
\cline { 2 - 6 } \multicolumn{1}{c|}{} & \multicolumn{2}{c||}{$120 \mathbf{~ k m / h}$} & \multicolumn{2}{c|}{$\mathbf{1 0 0} \mathbf{~ k m} / \mathbf{h}$} & \multicolumn{2}{c|}{$\mathbf{8 0} \mathbf{~ k m} / \mathbf{h}$} \\
\hline $\begin{array}{c}\text { Difference } \\
\text { between Week } \\
\text { N and Week 0 }\end{array}$ & $\begin{array}{c}\text { Harsh - } \\
\text { Control }\end{array}$ & $\begin{array}{c}\text { Soft - } \\
\text { Control }\end{array}$ & $\begin{array}{c}\text { Harsh - } \\
\text { Control }\end{array}$ & $\begin{array}{c}\text { Soft - } \\
\text { Control }\end{array}$ & $\begin{array}{c}\text { Harsh - } \\
\text { Control }\end{array}$ & $\begin{array}{c}\text { Soft }- \\
\text { Control }\end{array}$ \\
\hline $\begin{array}{c}\text { Week 1 - } \\
\text { Week 0 }\end{array}$ & $-6.61^{* *}$ & $-4.80^{* *}$ & $-4.96^{* *}$ & $-2.97 * *$ & $-1.32^{* *}$ & $-1.47^{* *}$ \\
\hline $\begin{array}{c}\text { Week 2 - } \\
\text { Week 0 }\end{array}$ & $-7.00^{* *}$ & $-5.56^{* *}$ & $-6.07^{* *}$ & $-5.41^{* *}$ & -0.95 & -0.81 \\
\hline $\begin{array}{c}\text { Week 3 - } \\
\text { Week 0 }\end{array}$ & -0.94 & -2.05 & -4.53 & -4.57 & -0.97 & -1.07 \\
\hline
\end{tabular}


We previously found that warnings to errant drivers in countries with the $80 \mathrm{~km} / \mathrm{h}$ speed limit were less effective in reducing the number of speeding drivers compared to countries higher speed limits (Table 6). This is in line with other sources that report lower compliance when speed limits are too low, as many people find the limitations too restrictive and impractical (TRB, 1998). However, the additional analysis conducted in this section shows that the treatment resulted in lower speeds among the speeding drivers from countries with the $80 \mathrm{~km} / \mathrm{h}$ speed limit (even if they did not slow down to be below the legal speed limit).

\subsubsection{Groups who received a warning had a lower mean speed.}

During congestion, vehicles are all travelling at approximately the same speed and it is impossible to speed. There is a high occurrence of traffic congestion in many of the South East Asian cities where this study was conducted. Therefore, by taking the average speeds for the drivers' entire journey, results become skewed towards lower speeds and there is no difference between speeding and non-speeding drivers. Therefore for this analysis, we excluded instances where the vehicle speed was below $17.3 \mathrm{~km} / \mathrm{h}$, which is the mean speed that a vehicle travels during congestion in these cities (Boquet, 2010).

Based on this analysis, we found that the Harsh warning reduced the mean speed by a statistically significant amount for all groups (Tables 11, 12 and 13).

Table 11: Mean speeds $(\mathrm{km} / \mathrm{h})$ of each group in each week.

\begin{tabular}{|c|c|c|c||c|c|c|c|c|c|}
\cline { 2 - 9 } \multicolumn{1}{c|}{} & \multicolumn{3}{|c|}{$\mathbf{1 2 0} \mathbf{~ k m} / \mathbf{h}$} & \multicolumn{3}{c|}{$\mathbf{1 0 0} \mathbf{~ k m} / \mathbf{h}$} & \multicolumn{3}{c|}{$\mathbf{~ k m / h}$} \\
\hline & $\begin{array}{c}\text { Harsh } \\
\text { Grou } \\
\mathbf{p}\end{array}$ & $\begin{array}{c}\text { Soft } \\
\text { Group }\end{array}$ & $\begin{array}{c}\text { Contro } \\
\mathbf{l} \\
\text { Group }\end{array}$ & $\begin{array}{c}\text { Harsh } \\
\text { Group }\end{array}$ & $\begin{array}{c}\text { Soft } \\
\text { Group }\end{array}$ & $\begin{array}{c}\text { Contro } \\
\mathbf{l} \\
\text { Group }\end{array}$ & $\begin{array}{c}\text { Harsh } \\
\text { Group }\end{array}$ & $\begin{array}{c}\text { Soft } \\
\text { Group }\end{array}$ & $\begin{array}{c}\text { Control } \\
\text { Group }\end{array}$ \\
\hline $\begin{array}{c}\text { Week 0 } \\
\text { (Pre- } \\
\text { warning) }\end{array}$ & 52.83 & 52.95 & 52.45 & 53.75 & 53.53 & 52.75 & 36.05 & 36.45 & 36.44 \\
\hline $\begin{array}{c}\text { Week 1 } \\
\text { (Post- } \\
\text { warning) }\end{array}$ & 48.75 & 50.45 & 51.16 & 49.03 & 51.1 & 51.72 & 35.15 & 35.74 & 35.99 \\
\hline $\begin{array}{c}\text { Week 2 } \\
\text { (Retention } \\
\text { W1) }\end{array}$ & 49.06 & 50.84 & 50.96 & 51.01 & 51.43 & 51.84 & 35.25 & 35.88 & 35.8 \\
\hline $\begin{array}{c}\text { Week 3 } \\
\text { (Retention } \\
\text { W2) }\end{array}$ & 49.89 & 51.67 & 50.41 & 52.46 & 52.3 & 52.98 & 35.11 & 36.26 & 36.2 \\
\hline
\end{tabular}


Table 12: Difference in mean speeds $(\mathrm{km} / \mathrm{h})$ between subsequent weeks and Week 0. Significant differences are indicated at $* 1 \%$, * $5 \%$ and $* * * 1 \%$ levels, based on pairwise comparisons.

\begin{tabular}{|c|c|c|c|c|c|c|c|c|c|}
\hline & \multicolumn{3}{|c|}{$120 \mathrm{~km} / \mathrm{h}$} & \multicolumn{3}{|c|}{$100 \mathrm{~km} / \mathrm{h}$} & \multicolumn{3}{|c|}{$80 \mathrm{~km} / \mathrm{h}$} \\
\hline & $\begin{array}{c}\text { Harsh } \\
\text { Grou } \\
\text { p }\end{array}$ & $\begin{array}{c}\text { Soft } \\
\text { Grou } \\
\text { p }\end{array}$ & $\begin{array}{c}\text { Contro } \\
1 \\
\text { Group }\end{array}$ & $\begin{array}{l}\text { Harsh } \\
\text { Group }\end{array}$ & $\begin{array}{l}\text { Soft } \\
\text { Group }\end{array}$ & $\begin{array}{c}\text { Contro } \\
1 \\
\text { Group }\end{array}$ & $\begin{array}{l}\text { Harsh } \\
\text { Group }\end{array}$ & $\begin{array}{l}\text { Soft } \\
\text { Group }\end{array}$ & $\begin{array}{c}\text { Control } \\
\text { Group }\end{array}$ \\
\hline $\begin{array}{l}\text { Week } 1 \text { - } \\
\text { Week } 0\end{array}$ & $\begin{array}{c}- \\
4.08^{* *}\end{array}$ & $-2.5 * *$ & -1.29 & $-4.72 * *$ & $\begin{array}{c}- \\
2.43^{* *}\end{array}$ & -1.03 & -0.9 & -0.71 & -0.45 \\
\hline $\begin{array}{l}\text { Week } 2 \text { - } \\
\text { Week } 0\end{array}$ & $\begin{array}{c}- \\
3.77 * * \\
\end{array}$ & -2.11 & -1.49 & $-2.74 * *$ & -2.1 & -0.91 & -0.8 & -0.57 & -0.64 \\
\hline $\begin{array}{l}\text { Week } 3 \text { - } \\
\text { Week } 0\end{array}$ & -2.94 & -1.28 & -2.04 & -1.29 & -1.23 & 0.23 & -0.94 & -0.19 & -0.24 \\
\hline
\end{tabular}

Table 13: Comparing the difference in mean speeds $(\mathrm{km} / \mathrm{h})$ for treatment versus control groups. Significant differences are indicated at $* 1 \%$, *5\% and $* * * 1 \%$ levels, based on pairwise comparisons.

\begin{tabular}{|c|c|c|c|c|c|c|}
\hline & \multicolumn{2}{|c|}{$120 \mathrm{~km} / \mathrm{h}$} & \multicolumn{2}{|c|}{$100 \mathrm{~km} / \mathrm{h}$} & \multicolumn{2}{|c|}{$80 \mathrm{~km} / \mathrm{h}$} \\
\hline $\begin{array}{c}\text { Difference } \\
\text { between Week N } \\
\text { and Week 0 }\end{array}$ & $\begin{array}{l}\text { Harsh - } \\
\text { Control }\end{array}$ & $\begin{array}{c}\text { Soft - } \\
\text { Control }\end{array}$ & $\begin{array}{l}\text { Harsh - } \\
\text { Control }\end{array}$ & $\begin{array}{c}\text { Soft - } \\
\text { Control }\end{array}$ & $\begin{array}{l}\text { Harsh - } \\
\text { Control }\end{array}$ & $\begin{array}{l}\text { Soft - } \\
\text { Control }\end{array}$ \\
\hline Week 1 - Week 0 & $-2.79 * *$ & $-1.21 * *$ & $-3.69 * *$ & $-1.40 * *$ & -0.45 & -0.26 \\
\hline Week 2 - Week 0 & $-2.28 * *$ & -0.62 & $-1.83 * *$ & -1.19 & -0.16 & 0.07 \\
\hline Week 3 - Week 0 & -0.90 & 0.76 & -1.52 & -1.46 & -0.70 & 0.05 \\
\hline
\end{tabular}

\section{Conclusion}

Previous studies have found that visual warnings can reduce speeding incidents (Chaurand et al., 2015; Jomaa, 2013). In this study, we expanded upon these findings to assess if warning speeding drivers would reduce the occurrence of speeding. This study focused on the effects of sending short warning messages to reduce excessive speeding in drivers. The work is part of a larger context of studying various interventions to promote safer driving behavior. Apart from the obvious benefits of reduced accidents and injuries through safer driving behavior, there are also economic benefits from corporate and government perspectives. Traffic accidents have high social and economic costs, such as causing road congestion, property damage, lost of man-hours and insurance payouts.

Safety is paramount to Grab, and we constantly strive to maintain a high standard of safety amongst our drivers. In the current study, we found that sending a single warning message to speeding drivers reduced their likelihood of speeding in the subsequent weeks, and that the effects were retained even 2 weeks after the message was sent. This retention effect provides insights on how frequently warning messages should be sent for maximum effectiveness. While this is preliminary indication that a one-off Harsh message can reduce speeding in the immediate weeks, further work is 
needed to determine the optimal warning frequency and assess if sending repeated messages will consistently produce similar effects.

We also found that Harsh messages with a 'loss' framing were more effective compared to Soft messages with 'gain' framing. This is in line with other work done in Asian populations (Uskul et al., 2009). Such findings have potential implications on how messages should be structured and tailored based on cultural context, and can be applied to other functions beyond safety, such as recruitment, sales, and marketing - more detailed experiments that test a wider range of messages is required to understand the specifics nuances here.

Further, knowing that the effect of a one-off reminder wears off after several weeks, it becomes even more critical to develop systems that provide regular feedback and allow drivers to self-monitor and modulate their behavior. Human behavior is closely related to both motivation and selfregulation (Bandura, 2001). By providing a system that provides regular feedback to drivers, they will be better equipped to evaluate their actions and conduct self-modulation. The work reported here is part of a larger effort to integrate various telemetry methods with quantitative and qualitative data in order to build more real-time safety. At the same time, we can combine these metrics with behavioral research to elicit reasons for speeding and other unsafe driving actions, in order to understand the root causes and design more robust interventions.

With the vast amount of data that is available through our large base of drivers, monitoring speeding is but one of the potential areas we can explore. Moving forward, we aim to identify not just occurrences of speeding, but also other unsafe road behaviors and how they are correlated with the probability of traffic accidents. Apart from using this information to identify, warn, and retrain delinquent drivers, such observations can be applied to other aspects, such as understanding the root causes of unsafe behavior and intervening there. These cross-functional efforts will serve to improve the overall safety and efficiency of transportation.

\section{References:}

1. Ajzen, I. (1985). From Intentions to Actions: A Theory of Planned Behavior. In J. Kuhl \& J. Beckmann (Eds.), Action Control: From Cognition to Behavior (pp. 11-39). Berlin, Heidelberg: Springer Berlin Heidelberg.

2. Bandura, A. (2001). Social cognitive theory: an agentic perspective. Annu Rev Psychol, 52, 1-26. doi:10.1146/annurev.psych.52.1.1

3. Bidasca, L., \& Townsend, E. (2014). The business case for managing road risk at work. Transportation Research Board. 
4. Boquet, Y. (2010). Changing mobilities in Asian cities. Paper presented at the The 2010 Southeast Asian Geography Conference, Hanoi, Vietnam.

5. Chaurand, N., Bossart, F., \& Delhomme, P. (2015). A naturalistic study of the impact of message framing on highway speeding. Transportation Research Part F: Traffic Psychology and Behaviour, 35, 37-44. doi:http://dx.doi.org/10.1016/j.trf.2015.09.001

6. Chisholm, D., Naci, H., Hyder, A. A., Tran, N. T., \& Peden, M. (2012). Cost effectiveness of strategies to combat road traffic injuries in sub-Saharan Africa and South East Asia: mathematical modelling study. BMJ, 344, e612. doi:10.1136/bmj.e612

7. De Leon, M., Cal, P., \& Sigua, R. (2005). Estimation of socioeconomic cost of road accidents in Metro Manila. Journal of the Eastern Asia Society for Transportation Studies, 6, 15.

8. Finch, D., Kompfner, P., Lockwood, C., \& Maycock, G. (1994). Speed, speed limits and accidents. TRL, PR58, 24.

9. Jomaa, D. Y., Siril; Dougherty, Mark. (2013). Review of the effectiveness of vehicle activated signs. Journal of Transportation Technologies, 3(2). doi:10.4236/jtts.2013.32012

10. Kareem, A. (2003). Review of global menace of road accidents with special reference to malaysia- a social perspective. Malays J Med Sci, 10(2), 31-39.

11. Lombard, D. N., Lombard, T. N., \& Winett, R. A. (1995). Walking to meet health guidelines: the effect of prompting frequency and prompt structure. Health Psychol, 14(2), 164-170.

12. Millar, M. G., \& Millar, K. U. (2000). Promoting Safe Driving Behaviors: The Influence of Message Framing and Issue Involvement. Journal of Applied Social Psychology, 30(4), 853-866. doi:10.1111/j.1559-1816.2000.tb02827.x

13. NHSTA. (2012). Traffic Safety Facts - 2012 Data. Retrieved from https://crashstats.nhtsa.dot.gov/Api/Public/ViewPublication/812021

14. Roethlisberger, F. J., Dickson, W. J., Wright, H. A., Pforzheimer, C. H., \& Western Electric, C. (1939). Management and the worker : an account of a research program conducted by the Western Electric Company, Hawthorne Works, Chicago. Cambridge, Mass.: Harvard University Press.

15. Schmid, K. L., Rivers, S. E., Latimer, A. E., \& Salovey, P. (2008). Targeting or tailoring? Mark Health Serv, 28(1), 32-37.

16. TRB. (1998). Managing Speed - Review of Current Practice for Setting and Enforcing Speed Limits. Retrieved from National Academy Press, Washington DC: 
17. Uskul, A. K., Sherman, D. K., \& Fitzgibbon, J. (2009). The cultural congruency effect: Culture, regulatory focus, and the effectiveness of gain- vs. loss-framed health messages. Journal of Experimental Social Psychology, 45(3), 535-541. doi:http://dx.doi.org/10.1016/j.jesp.2008.12.005

18. WHO. (2013). World Health Organisation - Global Health Observatory Data Repository. Retrieved from http://apps.who.int/gho/data/node.main.A998

19. WHO. (2015). World Health Organisation - Global Status Report on Road Safety 2015. Retrieved from 